\title{
MEASURING MANCUR OLSON: WHAT IS THE INFLUENCE OF CULTURE, INSTITUTIONS AND POLICIES ON ECONOMIC DEVELOPMENT?
}

\author{
Tomáš Evan ${ }^{a}$ (iD), Ilya Bolotov ${ }^{b}$
}

\begin{abstract}
$^{1}$
Mancur Olson wrote his influential study Big Bills Left on the Sidewalk: Why Some Countries are Rich, and Others Poor in 1996. In his paper, Olson claimed that the differences in economic development between countries are caused by only two factors: institutions and policies on the one hand and culture on the other. We attempt to test his conjecture using econometric modelling, combining and comparing it with a broadly defined orthodox production function in an indirect neoclassical notation (Solow-MinhasArrow-Chenery's SMAC framework). The "pseudo-production function" obtained is econometrically sound and of explanatory power similar to models including economic variables, although we find strong evidence of interdependence between capital-labour share and institutions and policies and culture. We consider the test, performed on panel data from 154 countries over five-year averages from 1980-2014, to be robust and consistent with Olson's ideas.
\end{abstract}

Keywords: Economic development, Olson' conjecture, institutions and policies, cultural values, Hofstede cultural frameworks, panel data

JEL Classification: C23, H50, O15, O38, O43

\section{Introduction}

Research on non-economic causes of economic growth (and development), traditionally attributed to heterodox (non-mainstream) economics, gained new momentum after Mancur Olson published his influential paper "Big Bills Left on the Sidewalk: Why Some Countries are Rich, and Others Poor" in 1996 (Olson, 1996). Olson claimed that the two main factors responsible for worldwide differences in wealth were (a) institutions and policies and, less significantly, (b) culture, whilst all other variables

a Czech Technical University, Prague, Czech Republic

b Prague University of Economics and Business, Prague, Czech Republic

Email: tomas.evan@fit.cvut.cz, ilya.bolotov@vse.cz 
played a secondary role. Summarized in Olson (1998, p. 378), the theory can be presented as follows: "If natural resource endowments, exogenous differences in capital stocks, cultural differences in individual responses to economic incentives and the features of the international system are not sufficient to explain economic development, it would by elimination seem that, broadly speaking, the institutions and policies of countries would have to be important." These ideas of Olson, despite conclusions derived from orthodox (mainstream) theoretical apparatus and his own empirical findings (among other, from data on migration) (Olson, 1982; Olson, 1987; Olson, 1996), albeit partly empirically backed by several subsequent empirical studies (consult further text for a list), have never been put under the same econometric scrutiny as were his other hypotheses such as institutional sclerosis, vested interests, etc.

In this paper, we attempt to fill the knowledge gap by constructing a quantitative estimation of Olson's conjecture on a panel data sample for 154 countries, five-year averages from 1980-2014, as if it were a "pseudo-production function" (although Olson was sceptical of the concept) by using the 1960s value-added per unit of labour formulation (aka SolowMinhas-Arrow-Chenery "SMAC" equation). This approach allows us to compare the results with nearly all the most frequently used production functions under the umbrella ofCES (constant elasticity of substitution) (Arrow et al., 1961) and its Lu-Fletcher extended version (a type of VES, variable elasticity of substitution; Lu and Fletcher, 1968). We compute a variety of statistics, adj. $R^{2}$, RMSE, AIC, BIC, omitted variables tests (here Ramsey's RESET), to compare Olson's model quality against the production functions and combined with them. We find the Olson "function" to be econometrically sound but no evidence that it is better than the existing mainstream models. This leads us to believe, in agreement with several previous studies, that Olson's ideas are correct but institutional factors still cannot be considered the only explanation of differences in wealth between countries.

\section{Literature Review: Mainstream versus Heterodox}

The introduction of the (aggregate) production function as a means of explaining output (per capita; consult Kurz, 1986; Mishra, 2007 for a detailed historical analysis) had a profound impact on a variety of economic fields, from economic history through macroeconomic policy to development economics. It was and in many ways remains the core of the mainstream theory; consult the works of Robinson (1953), Robinson (1955), Solow (1957), Mankiw et al. (1992), Klump, and Preissler (2000), Temple (2006), Acemoglu (2009) or Aghion et al. (2009). By its very focus, it is also implicitly and often explicitly opposed to non-economic explanations of economic growth. To put forward just one of many examples, (Acemoglu et al., 2005, pp. 3-4), when providing evidence 
on the causes of European economic growth after $1500 \mathrm{AD}$, rule out the "importance of certain distinctive European characteristics, such as culture, religion, geography, and features of European state system. Instead, it is consistent with theories that emphasize the importance of profits made in Atlantic trade, colonialism, and slavery". Indeed, somehow the readiness to accept influence of political or legal institutions, culture or value systems as sources of economic development became an "anathema" for many mainstream economists in the past; consult Jackson (1993) for an overview.

However, evidence of heterodox researchers over the last four decades such as North (1990), Granato et al. (1996), Pryor (2008) or Tabellini (2010), among many others, ${ }^{1}$ suggested with ever growing confidence that large disparities in economic growth across regions and countries can be attributed not only to differences in institutions but also to culture. These economists were in turn reflecting old themes of Weber's "The Protestant Ethics and the Spirit of Capitalism" (Weber, 2011) and possibly both great books of Adam Smith (Smith, 2007; Smith, 2011). It became apparent, as Boettke put it, that "we cannot assume away cultural influences as economists have often done" (Williamson, and Mathers, 2011, p. 314).

Mainstream economics has been criticized by different schools but along the same lines for decades. In stark opposition to mainstream dependence on theoretical and mathematical models, the Austrian School claimed that information about one's wants and needs is always personal, tied to an individual and that this knowledge therefore exists in society only in a diffuse mode and cannot be used for a general equilibrium model (Hayek, 1945). These disagreements have been well known ever since 1919, or the beginning of the debate over the economic rationality of socialism, where mainstream economists declared, to their great shame, that economically there was nothing wrong with socialism (Mises, 1951; Hayek, 1955; Rothbard, 2006). Similarly, behavioural economists' view on human rationality can hardly be reconciled with mainstream economics. From rare events (Taleb, 2007) to risk-taking (Thaler, 1980, p. 476) to workings of memory, they prove the mainstream economic theory about rational, selfish human beings with immutable tastes to be wrong as suggested in Nobelist Daniel Kahneman's book “Thinking, Fast and Slow", which is full of practical examples of human irrationality (Kahneman, 2011).

Institutional economics is also highly critical of mainstream economics, as Douglass C. North put it: "it is frictionless theory in a world in which the frictions are where the action is, and it is static in the world in which dynamic change is going

1 For a more comprehensive bibliography consult, for example, (Mathers and Williamson, 2011) and (Williamson and Mathers, 2011). 
on at an unprecedented rate" (North, 1995, p. 7). Just as the other two schools do, North finds the core shortcoming to be the unrealistic rationality assumption. Moreover, he finds that the neoclassic model is static, i.e., it does not permit time and economic change and development are therefore problematic.

According to North, we live under conditions of uncertainty and, thus, in both cases of friction and economic change, it is patently false to claim that individuals know what their interests are and are able to act accordingly. He uses Ronald Coase's $(1937,1960)$ concept of transaction costs to both endorse and criticize neoclassical theory. Efficient markets can only exist when it is costless to transact. This is a rare situation. And, when it is costly to transact, institutions matter (North, 1992). Institutions are thus crucial determinants of the efficiency of markets. Institutions are rules of the game and come as formal rules (such as laws and regulations) and informal constraints (such as norms of behaviour, even self-imposed ones). The latter constitutes much of what is called culture in the society (North, 1989). "Culture consists of the intergenerational transfer of knowledge, values, and norms; and it varies radically among different ethnic groups and societies." (North, 1992, p. 4)

The individual poses mental models "in part culturally derived, partly acquired through experience, and partly non-culturally and non-locally learned" (North, 1992, p. 4). Also, as known by Hayek's term "collective learning", our experience in using our mental models that prove workable through the test of time, become embedded in language, institutions and even technology (North, 1995). Environmental feedback plays a primary role in determining whether our mental model will be incrementally stabilized or modified. However, nothing guarantees the correct reception of environmental feedback. "The mind actively interprets all sensory input, the message regarding the success or failure of the solution attempted will often be misinterpreted. Indeed, the persistence throughout the history of dogmas, myths, superstitions, and ideologies based on such flawed belief systems calls us to pay as much attention to learning that produces such beliefs as we do to learning that appears to interpret correctly the problems confronting humans." (Mantzavinos et al., 2004, p. 76)

North concerned himself with the First Economic (or Neolithic) Revolution (1977) as well as the conditions for the second one (Industrial Revolution) (North, 1958; 1963; 1968), which are ideal case studies for economic performance and institutional change. The economic change allowed by institutional change is the clear focus of North's later work (North, 1989; 1994) connected with learning (North, 1995; Mantzavinos et al., 2004) and can be summarized as outlined below. As scarcity exists, competition is necessary, and organizations invest in learning in order to survive. The rate of learning determines the speed of economic change while the kind of learning decides the direction 
of economic change. Institutions and culture can block or delay the new contraction forms necessary but sometimes the needed alteration of rules or norms is achieved. Institutions are modified, allowing lower transaction costs and more efficient markets and improved economic performance.

On the other hand, finding statistically significant correlations, let alone causations, is rather difficult and, to the extent to which economic science with its quest for sources of growth depends on other social sciences and humanities, it loses its strength in quantitative analysis and is criticized because of ill-defined concepts and varying definitions (consult, for example, Beugelsdijk, 2006).

As stated above, North (1990) identifies culture as formal (constitutions, laws and enforced constrains) and informal (traditions, customs, taboos or sanctions). Olson (1996) divides culture into personal and civic, with the former being described as marketable human capital and the latter as that affecting incomes by influencing public policies and institutions. There are numerous other definitions, but we will, as others have done before us, broadly identify institutions and policies with formal (civic) culture, and we will refer to informal (personal) culture just as culture.

Culture itself has been defined in several ways with varying degrees of usefulness with regard to economics and theories of economic growth in particular. Hofstede (2011) developed a concept of seven cultural dimensions, three of which seem to have significant relation to economic growth. Schwarz formulated a theory of basic human values (Schwartz, 1992) with ten values measured by the Schwarz value survey, whilst Tabellini's indicators of individual values and beliefs (trust, respect, control, obedience) (Tabellini, 2008; Tabellini, 2010) served as a base for research by several scholars applying a historical perspective. This perspective allowed them to explore the impact of historical institutions on culture, which in turn influences economic development, including output and growth. With his specific approach, Tabellini proved that culture plays a role even in societies characterized by strong formal institutions (Tabellini, 2010). However, the ways through which culture is transmitted to future generations have been discovered only relatively recently (Tabellini, 2008; Tabellini, 2010; Guiso et al., 2015). This transfer of culture from one generation to another is what makes it so persistent but also elusive. The interaction between culture and institutions is also most likely one of bilateral implications with varying strength of those implications over time. This means that culture might make it easy (or difficult) for its followers to become economically successful but it can also help (or block) pro-economic growth institutions and policies. Williamson (2009) came arguably closest to the description of this relationship, building on previous research (Boettke et al., 2008), in suggesting that institutions wanting to promote economic development must first be "mapped" onto 
culture. In her further work (Williamson and Mathers, 2011), she based the economic culture variable on methodology found in Tabellini (2010) while comparing it with the Fraser Institute's Economic Freedom of the World Index. Williamson came to a conclusion that culture, while significant in several specifications, has smaller effects than institutions. She claims that the two are substitutes, with culture being crucial if institutions supportive to economic growth are absent but losing significance when those institutions are well established (Williamson and Mathers, 2011). Williamson's conclusion is similar to that of Olson (1998).

Yet, there might be methodological problems with the current line of theorizing about culture as highlighted by Beugelsdijk (2006), for example. He criticized attempts to explain differences in economic development by differences in what he saw as the illdefined concept of trust. He considered conclusions from one question in a cultural survey to be (overly) simplistic given the complex nature of the trust concept. In this way, according to Beugelsdijk (2006), "trust" might not be a measure of culture but rather of well-functioning institutions.

\section{Olson's Methodology as a Special Case}

Two years prior to his death, Mancur Olson published an influential paper "Big Bills Left on the Sidewalk: Why Some Countries are Rich, and Others Poor" (Olson, 1996), ${ }^{2}$ claiming that the differences in income delimited by "national borders" can be explained neither by the distribution of the world's stock of productive knowledge nor by the ratio of population to land or to natural resources. Comparing neoclassical predictions on migration and capital flows to the research of Lucas (1990) and based on Borjas $(1985 ; 1987)$ and Clague (1991), he disregarded all of these factors in favour of just two: institutions and culture. The former was considered dominant whilst the latter additional, at best. Olson generally considered culture more of a hindrance to economic development than a "blessing" and was aware of the long-lasting impact of it: "the Latin American who swims the Rio Grande is not thereby instantly baptized with Protestant ethic ... it takes time to erase generations of socialization: if cultural or other traits of a people could be changed overnight, they could not be significant barriers to development" (Olson, 1996, p. 22). This conjecture, of dominance of institutions and their prevalence over culture, which Olson started working on in the past (Olson, 1982; Olson, 1987), was also repeated in his subsequent works; consult, for example Olson (1998).

2 The number of citations of the mentioned study exceeds 1480 in Google Scholar, 260 in Clarivate Analytics' Web of Science (Social Sciences Citations Index) and 360 in Elsevier's Scopus. 
To establish how much more significant institutions are in comparison to culture, Olson developed a thought experiment using US immigration data. He considered immigrants from West Germany and Haiti as examples of ones from the most and the least successful economies in the world respectively. Whilst the income in West Germany was about ten times higher than the income in Haiti, the income of immigrants in the US was only roughly twice higher in favour of West Germans. A similar difference was found between Switzerland and Egypt or Japan and Guatemala (Olson, 1996, pp. 18-19). Olson came to the conclusion that US institutions and economic policies levelled the playing field for both groups of immigrants. (Olson, 1996; Olson, 1998). His conclusion was predominantly backed by several subsequent empirical studies on differences across (macro) regions and on sources of productivity growth; consult Lall et al. (2002). These studies discovered a positive correlation between productivity growth and civic, economic and political liberty in 30 countries in the Western hemisphere in 1978-1994 (Tabellini, 2008; Tabellini, 2010; Williamson, 2009; Law et al., 2013; Kapas and Czegledi, 2017), measuring a bidirectional causality between institutions and economic development in data from 60 countries. Institutions and policies were found to be of "primary importance" for economic development in the long run based on a cross-country regression analysis.

\section{Model}

The main difficulty in testing Olson's conjecture econometrically and comparing it to orthodox theories lies in finding a suitable model framework, given the fact that most known (growth) models explaining economic development are based on aggregate production functions (Solow, 1957; Mankiw et al., 1992; Klump, and Preissler, 2000; Temple, 2006; Acemoglu, 2009). On the contrary, Olson criticized the concept in his works (Olson, 1996; Olson, 1998). Still, we believe that we found a methodological "workaround", considering Olson's conjecture to be a "pseudo-production function" (quotation marks indicate distinction from the mainstream concept of a pseudo-production function, as examined by Shaikh (2005)), since any hypothetical equation with "Olson's factors" on its righthand side will have the same left-hand side as an (aggregate) production function as defined by economic theory (Shephard, 1970, pp. 13-63).

\subsection{Methodology}

Kurz (1986) and Mishra (2007) provide a wide range of single, joint and aggregate production functions, out of which the Solow-Minhas-Arrow-Chenery "SMAC" general framework from the 1960s seems to be the most suitable for our case. The SMAC not 
only allows modelling (direct or indirect) of the most frequently used Cobb-Douglas, fixed-coefficient (Walras, Leontief, etc.), CES (constant elasticity of substitution) and even a case of VES (variable elasticity of substitution) ${ }^{3}$ production functions, but also the application of any institutionalist theory, by having the form of a single logarithmized (or multiplicative if untransformed) equation of value added per unit of labour (a measure of output) on the left-hand side and any possible combination of inputs on the right-hand side. The equation is valid under the "neoclassical" conditions of (a) two factors of production, $V=f(K, L)$, and (b) competitive labour and product markers, $W=\partial f(K, L) / \partial K=\partial f(K, L) / \partial L$, as defined by Arrow et al. (1961, pp. 228-229) and $\mathrm{Lu}$ and Fletcher (1968, pp. 449-450) in their respective formalization:

$$
\log (V / L)=\log \alpha+\sum_{i=1}^{k} \beta_{i} \log Z_{i}
$$

where $V$ is the total value added in the economy (income, gross domestic product, etc., possibly gross value added), $K$ is the capital stock, $L$ is the labour force, $W$ is the wage rate, $\alpha$ and $\beta_{i}, i=1, \ldots, k$ are coefficients of the model (in total $k+1$ ), and $Z_{i}, i=1, \ldots, k$ are the input factors (economic, such as $W$, or $K / L$, non-economic, such as Olson's factors, etc.). The estimation of the model may be performed using any estimator (OLS, GLS, ML, GMM, etc.) with or without constraints, as well as under robust (or clustered) standard errors, weights or any resampling techniques. To summarize, the SMAC framework can be characterized as a general indirect equation for most production functions, where the type of function is set by imposing restrictions on $\beta_{i}$ (which can be modelled using postestimation (non-)linear combinations of coefficients or Wald tests), and where the "traditional" form of the function is attained via a differential equation, as illustrated by Arrow et al. (1961, pp. 229-230) for Cobb-Douglas (possibly also fixedcoefficient production functions) and CES, and Lu, and Fletcher (1968, pp. 449-450) for their case of extended CES (VES).

\subsection{Formalization}

We consider the following SMAC indirect two-form model for Olson's conjecture in a panel data interpretation (the letter $j$ stands for the country and $t$ for the time unit):

$$
\begin{aligned}
& \log (V / L)_{j t}=\log \zeta+\sum_{i=1}^{m} \theta_{i} \log \operatorname{privHC}_{i, j t}+\sum_{i=1}^{n} \vartheta_{i} \log p u b H C_{i, j t} \\
& \log (V / L)_{j t}=\log \zeta+\sum_{i=1}^{m} \theta_{i} \log \operatorname{privHC}_{i, j t}+\sum_{i=1}^{n} \vartheta_{i} \log p u b H C_{i, j t}+\sum_{i=1}^{k} v_{i} \log Z_{i, j t}
\end{aligned}
$$


for its original "pure" form (2), where privHC $C_{i, j t}$ and $p u b H C_{i, j t}$ are proxies for private good (culture) and public good (institutions and policies) human capital, where $\beta_{\text {institutions }}>\beta_{\text {culture }}$, i.e., the marginal effect of $p u b H C_{i, j t}$ is greater than that of privHC $_{i, j t}$; and for its "weak" form (3), where the restrictions are relaxed, and the number of inputs can be augmented (if necessary); as compared to Cobb-Douglas (CD) / fixed-coefficient / CES / Lu-Fletcher VES general model:

$$
\log (V / L)_{j t}=\log \varphi_{0}+\varphi_{1} \log W_{j t}+\varphi_{2} \log (K / L)_{j t}
$$

where Lu-Fletcher VES is $V_{j t}=\gamma\left[\delta K_{j t}^{-\rho}+(1-\delta) \eta(K / L)_{j t}^{-c(1+\rho)} L_{j t}^{-\rho}\right]^{-1 / \rho}$ under $\rho=1 / \varphi_{1}-1, \eta=1-\varphi_{1} / 1-\varphi_{1}-c, \varphi_{0}^{-1 / \varphi_{1}}=(1-\delta) \gamma^{-\rho}$, and $\boldsymbol{\beta}=\delta \gamma^{-\rho}(\boldsymbol{\beta}$ is the constant of integration, obtained from the aforementioned differential equation, and $c$ is the Lu-Fletcher alternative indication of $\left.\varphi_{1}\right)$; CES is $V_{j t}=\gamma\left[\delta K_{j t}^{-\rho}+(1-\delta) L_{j t}^{-\rho}\right]^{-1 / \rho}$ under $\rho=1 / \varphi_{1}-1, \varphi_{0}^{-1 / \varphi_{1}}+\boldsymbol{\beta}=\gamma^{-\rho}, \boldsymbol{\beta} \gamma^{\rho}=\delta$, and $\varphi_{2}=0(\boldsymbol{\beta}$ is an ancillary variable of integration, not specified here for the reasons of simplicity); Cobb-Douglas is defined as $V_{j t}=\lim _{\rho \rightarrow 0} \gamma\left[\delta K_{j t}^{-\rho}+(1-\delta) L_{j t}^{-\rho}\right]^{-1 / \rho} \gamma K_{j t}^{-\rho}$ (or indirectly expressed in (4) as $\varphi_{1}=1$ and $\left.\varphi_{2}=0\right)$ and the fixed-coefficient is defined as $V_{j t}=\lim _{\rho \rightarrow \infty} \gamma\left[\delta K_{j t}^{-\rho}+(1-\delta) L_{j t}^{-\rho}\right]^{-1 / \rho}$ or indirectly expressed in (4) as $\varphi_{1}=\varphi_{2}=0$ ). The SMAC and traditional notations for production functions will be regarded as equivalent in this paper, since we consider the assumptions defined in the methodology of the model to be true. ${ }^{4}$

\subsection{Hypotheses}

Based on Olson (1996; 1998), we define three hypotheses for econometric testing:

H1: Olson's model is correctly specified.

H2: Olson's model is better at predicting income levels than the mainstream production function.

H3: $\beta_{\text {institutions }}>\beta_{\text {culture }}$ for marginal effects.

4 The validity of assumptions provides us with formal simplicity, but it can also bias the results. To minimize this risk, after the initial estimation, we perform an additional bootstrap estimation of standard errors in the model. Inferring directly from the data will give us more confidence for the final interpretation. 


\section{Data}

To estimate the model, we create a sample panel dataset of 154 countries over fiveyear averages from 1980-2014 in order to compensate for missing values (which are nonetheless still present; consult Table 2) and the influence of business cycles, compiled from data of the University of Groningen's Penn World Tables 9.0, (Feenstra et al., 2016) $)^{5}$, ILOSTAT database 2018, Occupational Wages around the World (OWW) Database (Freeman and Oostendorp, 2002; Freeman and Oostendorp, 2001), Hofstede and Bond's dataset from 2015, data from Transparency International and the Internet Centre for Corruption Research (ICGG) from 2016, compiled and imputed with the help of moving averages by Evan and Bolotov $(2017 ; 2014)$, and the Frazer Institute's Economic Freedom of the World dataset from 2018; consult Table 1. Olson's privHC $C_{i, t}$ is proxied with four variables, the average years of schooling priv_hc_yr_sch, the rate of individualism priv_hc_ind the rate of uncertainty avoidance priv_hc_uai, and the rate of long-term orientation priv_hc_ltowvs; and $p u b_{-} H C_{i, j t}$, with five variables, the perception of corruption pub_hc_cpi, the quality of the legal system and property rights priv_hc_ltowvs, the "soundness" of money pub_hc_sm, the rate of freedom to trade internationally pub_hc_fti, and the degree of regulation pub_hc_reg; which is the closest to the word-by-word definition of culture and institutions and policies, as specified in Olson (1996, pp. 15-16), that we could get in our efforts. Unfortunately, Hofstede and Bond's dataset offers only time-invariant proxies, which adversely affects $\operatorname{privHC}_{i, j t}$ in all subsequent estimations. On the other hand, to compensate for the influence of prices and exchange rates on economic variables, we use data in current prices and in both the US dollar and local currency terms.

Table 1 presents an overview of our dataset with data sources indicated; consult the Appendix for a more detailed summary including descriptive statistics (means, standard deviations, etc.).

5 The Groningen Growth and Development Center is the current compiler and publisher of Penn World Tables. 
Table 1: Dataset description and sources

\begin{tabular}{|c|c|}
\hline Variable name & Description \\
\hline \multicolumn{2}{|r|}{ VALUE ADDED / INCOME } \\
\hline ngdp_lcu & GDP at current national prices, PWT 9.0 (mil. LCU) \\
\hline$n g d p$ & GDP at current national prices, PWT 9.0 (mil. USD) \\
\hline ngdp_lcu_per_l & $=$ ngdp_lcu /I \\
\hline ngdp_per_l & $=n g d p / I$ \\
\hline \multicolumn{2}{|r|}{ INPUTS - ORTHODOX (Z) } \\
\hline k_lcu & Capital stock at current national prices, PWT 9.0 (mil. LCU) \\
\hline$k$ & Capital stock at constant 2011 national prices, PWT 9.0 (mil. 2011 USD) \\
\hline k_lcu_per_l & $=\mathrm{k} \_\mathrm{Icu} / \mathrm{I}$ \\
\hline k_per_l & $=\mathrm{k} / \mathrm{l}$ \\
\hline I & Labour force, PWT 9.0 + ILOSTAT, number of persons (mil.) \\
\hline \multicolumn{2}{|r|}{ INPUTS - OLSON (Z) } \\
\hline priv_hc_yr_sch & Olson's marketable human capital, index (Part 1), Average years of schooling, PWT 9.0 \\
\hline priv_hc_ind & Olson's marketable human capital, index (Part 2), Hofstede-Bond, normalized (0-100) \\
\hline priv_hc_uai & Olson's marketable human capital, index (Part 3), Hofstede-Bond, normalized (0-100) \\
\hline priv_hc_ltowvs & Olson's marketable human capital, index (Part 4), Hofstede-Bond, normalized (0-100) \\
\hline pub_hc_cpi & $\begin{array}{l}\text { Olson's quality of institutions, index (Part 1), ICGG + Transparency International } \\
\text { (imputed by Bolotov and Evan, } 2013 \text { and 2017) (0-100) }\end{array}$ \\
\hline pub_hc_lspr & Olson's quality of institutions, index (Part 2), Fraser Institute (EFW) (0-100) \\
\hline pub_hc_sm & Olson's quality of institutions, index (Part 3), Fraser Institute (EFW) (0-100) \\
\hline pub_hc_fti & Olson's quality of institutions, index (Part 4), Fraser Institute (EFW) (0-100) \\
\hline pub_hc_reg & Olson's quality of institutions, index (Part 5), Fraser Institute (EFW) (0-100) \\
\hline \multicolumn{2}{|r|}{ PRICES } \\
\hline$e$ & Exchange rate, market + estimated, PWT 9.0 (national currency/USD) \\
\hline$w_{-} l c u \_m$ & Average monthly wage, NBER (OWW) + v_gdp_lcu * labsh / 12 from PWT 9.0 (LCU) \\
\hline$w \_m$ & Average monthly wage, NBER (OWW) + v_gdp * labsh / 12 from PWT 9.0 (in USD) \\
\hline \multicolumn{2}{|r|}{ NOTES_AND_REMARKS } \\
\hline note_l & Note: (ILOSTAT) Source of labour force data, information on series \\
\hline note_e & Note: Exchange rate, national currency/USD (market+estimated) \\
\hline note_w & Note: NBER (OWW) currency and conversion method \\
\hline note_w_labsh & Note: PWT 9.0 (labsh) method \\
\hline
\end{tabular}

Source: authors, Stata 
Table 2: Missing values

\begin{tabular}{l|c}
\hline Variable name & Numbers \\
\hline$n g d p \_l c u$ & 47 \\
\hline ngdp & 47 \\
\hline ngdp_lcu_per_l & 693 \\
\hline ngdp_per_l & 693 \\
\hline k_lcu & 55 \\
\hline$k$ & 47 \\
\hline k_lcu_per_l & 695 \\
\hline k_per_l & 693 \\
\hline I & 693 \\
\hline priv_hc_yr_sch & 133 \\
\hline pub_hc_lspr & 301 \\
\hline pub_hc_sm & 261 \\
\hline pub_hc_fti & 300 \\
\hline pub_hc_reg & 278 \\
\hline$e$ & 41 \\
\hline w_m & 234 \\
\hline w_lcu_m & 234 \\
\hline Total & 734 \\
\hline Source:autors, & \\
\hline
\end{tabular}

Source: authors, Stata

We do not recur to multiple imputation, so the effective estimation sample varies between 300 and 350 observations given a large number of missing observations in $l$ (labour force); consult Table 2.

\section{Results}

The model was estimated with the help of the OLS (ML for some statistics) estimator under fixed effects (FE), which proved to be the most efficient as compared to pooled and random effects (RE), based on the corresponding panel effects and Hausman tests; consult Tables 3 and 4. We disregard unit root tests and co-integration analysis because of the short time series ( 7 five-year averages). The tables compare four cases: Olson's conjecture (1), the general production function (4), and combinations (2) and (3). Most statistics, AIC, etc., were calculated prior to robust standard errors. 
Table 3: Estimations in SMAC framework, USD, current prices, FE with robust std. errors

\begin{tabular}{|c|c|c|c|c|}
\hline & (1) & (2) & (3) & (4) \\
\hline & Pure Olson & Olson + CES & Olson + VES & General PF \\
\hline log_priv_hc_yr_sch & $\begin{array}{l}2.4859^{* * *} \\
(9.50)\end{array}$ & $\begin{array}{l}0.6932^{* *} \\
(3.12)\end{array}$ & $\begin{array}{l}0.2303 \\
(1.39)\end{array}$ & - \\
\hline log_priv_hc_ind & $\begin{array}{l}0.0000 \\
(.)\end{array}$ & $\begin{array}{l}0.0000 \\
(.)\end{array}$ & $\begin{array}{l}0.0000 \\
(.)\end{array}$ & - \\
\hline log_priv_hc_uai & $\begin{array}{l}0.0000 \\
(.)\end{array}$ & $\begin{array}{c}0.0000 \\
(.)\end{array}$ & $\begin{array}{c}0.0000 \\
(.)\end{array}$ & - \\
\hline log_priv_hc_ltowvs & $\begin{array}{c}0.0000 \\
(.)\end{array}$ & $\begin{array}{c}0.0000 \\
(.)\end{array}$ & $\begin{array}{c}0.0000 \\
(.)\end{array}$ & - \\
\hline log_pub_hc_cpi & $\begin{array}{l}0.3608^{*} \\
(2.20)\end{array}$ & $\begin{array}{l}0.0726 \\
(0.82)\end{array}$ & $\begin{array}{c}0.0198 \\
(0.41)\end{array}$ & - \\
\hline log_pub_hc_lspr & $\begin{array}{l}-0.0538 \\
(-0.22) \\
\end{array}$ & $\begin{array}{l}0.1197 \\
(0.70) \\
\end{array}$ & $\begin{array}{l}0.3138^{*} \\
(2.32)\end{array}$ & - \\
\hline log_pub_hc_sm & $\begin{array}{l}0.3400^{* * *} \\
(6.72)\end{array}$ & $\begin{array}{l}0.0327 \\
(0.69) \\
\end{array}$ & $\begin{array}{l}0.0903^{*} \\
(2.29) \\
\end{array}$ & - \\
\hline $\log _{-} p u b \_h c \_f t i$ & $\begin{array}{l}-0.4333^{*} \\
(-2.19) \\
\end{array}$ & $\begin{array}{l}0.0091 \\
(0.07) \\
\end{array}$ & $\begin{array}{c}-0.2336^{* *} \\
(-3.33)\end{array}$ & - \\
\hline log_pub_hc_reg & $\begin{array}{l}0.8279^{* * *} \\
(4.28)\end{array}$ & $\begin{array}{c}0.1699 \\
(1.75) \\
\end{array}$ & $\begin{array}{l}0.0303 \\
(0.40)\end{array}$ & - \\
\hline $\log _{-} w \_m$ & - & $\begin{array}{c}0.8089^{* * *} \\
(13.69)\end{array}$ & $\begin{array}{l}0.6608^{* * *} \\
(12.99) \\
\end{array}$ & $\begin{array}{l}0.7427^{* * *} \\
(20.43) \\
\end{array}$ \\
\hline log_k_per_l & - & - & $\begin{array}{l}0.6725^{* * *} \\
(7.06)\end{array}$ & $\begin{array}{l}0.6802^{* * *} \\
(8.94)\end{array}$ \\
\hline _cons & $\begin{array}{l}1.8047^{*} \\
(2.32)\end{array}$ & $\begin{array}{l}1.9934^{* * *} \\
(4.27)\end{array}$ & $\begin{array}{l}-3.4129^{* * *} \\
(-4.60)\end{array}$ & $\begin{array}{l}-3.1386^{* * *} \\
(-4.41)\end{array}$ \\
\hline$N$ & 344 & 314 & 314 & 345 \\
\hline $\operatorname{Adj} . R^{2}$ & 0.6500 & 0.8990 & 0.9430 & 0.9380 \\
\hline RMSE & 0.2121 & 0.1170 & 0.0881 & 0.0955 \\
\hline AIC & -83.5807 & $-4.5 \mathrm{E}+02$ & $-6.3 \mathrm{E}+02$ & $-6.4 \mathrm{E}+02$ \\
\hline $\mathrm{BIC}$ & -56.6962 & $-4.2 \mathrm{E}+02$ & $-5.9 \mathrm{E}+02$ & $-6.3 \mathrm{E}+02$ \\
\hline $\begin{array}{l}\text { Panel effects test } \\
\text { (Pooled / FE) }\end{array}$ & $\begin{array}{c}0.0000 \\
(17.1221)\end{array}$ & $\begin{array}{l}0.0000 \\
(9.2372)\end{array}$ & $\begin{array}{c}0.0000 \\
(11.4819)\end{array}$ & $\begin{array}{c}0.0000 \\
(12.4470)\end{array}$ \\
\hline $\begin{array}{l}\text { Hausman test } \\
\text { (RE / FE) }\end{array}$ & $\begin{array}{c}0.0000 \\
(34.9994)\end{array}$ & $\begin{array}{c}0.0475 \\
(14.2153) \\
\end{array}$ & $\begin{array}{c}0.0000 \\
(45.9216) \\
\end{array}$ & $\begin{array}{c}0.0000 \\
(63.3246)\end{array}$ \\
\hline $\begin{array}{l}\text { Ramsey RESET } \\
\text { (quadratic) }\end{array}$ & $\begin{array}{c}0.0294 \\
(4.8058) \\
\end{array}$ & $\begin{array}{c}0.2565 \\
(1.2949)\end{array}$ & $\begin{array}{l}0.0681 \\
(3.3624) \\
\end{array}$ & $\begin{array}{l}0.1008 \\
(2.7153)\end{array}$ \\
\hline $\begin{array}{l}\text { Ramsey RESET } \\
\text { (quadratic + cubic) }\end{array}$ & $\begin{array}{c}0.0934 \\
(2.3964) \\
\end{array}$ & $\begin{array}{c}0.2544 \\
(1.3781) \\
\end{array}$ & $\begin{array}{c}0.1593 \\
(1.8536) \\
\end{array}$ & $\begin{array}{c}0.1945 \\
(1.6492) \\
\end{array}$ \\
\hline
\end{tabular}

Note: $t, F$ and $X^{2}$ statistics in parentheses; ${ }^{*} p<0.05,{ }^{* *} p<0.01,{ }^{* * *} p<0.001$

Source: authors, Stata 
Table 4: Estimations in SMAC framework, LCU, current prices, FE with robust std. errors

\begin{tabular}{|c|c|c|c|c|}
\hline & (1) & (2) & (3) & (4) \\
\hline & Pure Olson & Olson + CES & Olson + VES & General PF \\
\hline log_priv_hc_yr_sch & $\begin{array}{l}3.0141^{* * *} \\
(7.49)\end{array}$ & $\begin{array}{l}2.6881^{* * *} \\
(6.40)\end{array}$ & $\begin{array}{c}-0.0425 \\
(-0.23)\end{array}$ & - \\
\hline log_priv_hc_ind & $\begin{array}{c}0.0000 \\
(.)\end{array}$ & $\begin{array}{c}0.0000 \\
(.)\end{array}$ & $\begin{array}{c}0.0000 \\
(.)\end{array}$ & - \\
\hline log_priv_hc_uai & $\begin{array}{c}0.0000 \\
(.)\end{array}$ & $\begin{array}{c}0.0000 \\
(.)\end{array}$ & $\begin{array}{c}0.0000 \\
(.)\end{array}$ & - \\
\hline log_priv_hc_ltowvs & $\begin{array}{c}0.0000 \\
(.)\end{array}$ & $\begin{array}{c}0.0000 \\
(.)\end{array}$ & $\begin{array}{c}0.0000 \\
(.)\end{array}$ & - \\
\hline $\log _{-} p u b \_h c_{-} c p i$ & $\begin{array}{c}0.5308 \\
(1.91)\end{array}$ & $\begin{array}{c}0.3618 \\
(1.49)\end{array}$ & $\begin{array}{c}-0.0571 \\
(-1.02)\end{array}$ & - \\
\hline log_pub_hc_lspr & $\begin{array}{c}-0.4881 \\
(-1.12)\end{array}$ & $\begin{array}{c}-0.6887 \\
(-1.53)\end{array}$ & $\begin{array}{l}0.1103 \\
(1.06)\end{array}$ & - \\
\hline $\log _{-} p u b \_h c \_s m$ & $\begin{array}{l}0.4933^{*} \\
(2.38)\end{array}$ & $\begin{array}{c}0.2816 \\
(1.35) \\
\end{array}$ & $\begin{array}{c}0.1258 \\
(1.76) \\
\end{array}$ & - \\
\hline $\log _{-} p u b \_h c \_f t i$ & $\begin{array}{l}1.1009 \\
(1.24)\end{array}$ & $\begin{array}{c}0.9774 \\
(1.18)\end{array}$ & $\begin{array}{l}0.0136 \\
(0.09)\end{array}$ & - \\
\hline $\log _{\text {o }} p u b \_h c \_r e g$ & $\begin{array}{l}0.9344^{*} \\
(1.98)\end{array}$ & $\begin{array}{l}1.0799^{*} \\
(2.23)\end{array}$ & $\begin{array}{l}0.0176 \\
(0.22)\end{array}$ & - \\
\hline $\log _{-} w \_l c u \_m$ & - & $\begin{array}{c}0.1979^{*} \\
(2.15)\end{array}$ & $\begin{array}{l}0.0258^{* *} \\
(3.39)\end{array}$ & $\begin{array}{l}0.0405^{* * *} \\
(3.49)\end{array}$ \\
\hline log_k_lcu_per_l & - & - & $\begin{array}{l}0.9363^{* * *} \\
(22.87) \\
\end{array}$ & $\begin{array}{l}0.9702^{* * *} \\
(41.35)\end{array}$ \\
\hline _cons & $\begin{array}{c}-0.6878 \\
(-0.34)\end{array}$ & $\begin{array}{c}-0.5437 \\
(-0.29) \\
\end{array}$ & $\begin{array}{c}-0.7450 \\
(-1.68) \\
\end{array}$ & $\begin{array}{l}-1.1063^{* * *} \\
(-3.66)\end{array}$ \\
\hline$N$ & 344 & 314 & 312 & 343 \\
\hline Adj. $R^{2}$ & 0.6780 & 0.7220 & 0.9770 & 0.9740 \\
\hline RMSE & 0.2834 & 0.2705 & 0.0772 & 0.0870 \\
\hline AIC & 115.7573 & 77.9577 & $-7.0 \mathrm{E}+02$ & $-7.0 \mathrm{E}+02$ \\
\hline $\mathrm{BIC}$ & 142.6418 & 107.9528 & $-6.7 \mathrm{E}+02$ & $-6.9 \mathrm{E}+02$ \\
\hline $\begin{array}{l}\text { Panel effects test } \\
\text { (Pooled / FE) }\end{array}$ & $\begin{array}{c}0.0000 \\
(102.5299) \\
\end{array}$ & $\begin{array}{c}0.0000 \\
(15.1094) \\
\end{array}$ & $\begin{array}{c}0.0000 \\
(17.6682) \\
\end{array}$ & $\begin{array}{c}0.0000 \\
(21.7540)\end{array}$ \\
\hline $\begin{array}{l}\text { Hausman test } \\
\text { (RE / FE) }\end{array}$ & $\begin{array}{c}0.0000 \\
(49.1618)\end{array}$ & $\begin{array}{c}0.0000 \\
(164.8864)\end{array}$ & $\begin{array}{c}0.1402 \\
(12.2546)\end{array}$ & $\begin{array}{l}0.0000 \\
(22.8115)\end{array}$ \\
\hline $\begin{array}{l}\text { Ramsey RESET } \\
\text { (quadratic) }\end{array}$ & $\begin{array}{c}0.1017 \\
(2.7007)\end{array}$ & $\begin{array}{c}0.1394 \\
(2.2020)\end{array}$ & $\begin{array}{c}0.0000 \\
(26.1764)\end{array}$ & $\begin{array}{c}0.0000 \\
(33.3955)\end{array}$ \\
\hline $\begin{array}{l}\text { Ramsey RESET } \\
\text { (quadratic + cubic) }\end{array}$ & $\begin{array}{c}0.0000 \\
(29.6812)\end{array}$ & $\begin{array}{c}0.0000 \\
(32.9203)\end{array}$ & $\begin{array}{c}0.0000 \\
(13.0727)\end{array}$ & $\begin{array}{c}0.0000 \\
(18.8082)\end{array}$ \\
\hline
\end{tabular}

Note: $t, F$ and $X^{2}$ statistics in parentheses; ${ }^{*} p<0.05,{ }^{, * *} p<0.01,{ }^{* * * *} p<0.001$

Source: authors, Stata 
The goodness of fit statistics, adj. $R^{2}$, root mean square error (RMSE) and both information criteria (Akaike's and Schwarz's Bayesian ICs) tend to improve when transitioning from the "pure Olson" to the general production function, although cases (2) and (3) appear to be misspecified according to the Ramsey RESET tests in the US dollar terms (but not in local currencies, LCU). This supports our H1 set in the methodology section (that Olson's model is correctly specified, here in its pure form). Olson's model explains about $65.0 \%-67.8 \%$ of the variability, whilst modified versions explain $72.2 \%-89.9 \%$ and $94.3 \%-97.7 \%$, and the general production function even more, $93.8 \%-97.4 \%$, which speaks against our $\mathrm{H} 2$ (that a pure Olson model has better explanatory power). The estimated regression coefficients do not show a common pattern between cases and estimations (in some cases, probably, because of model misspecification), the most important of which in (1) being the ones of $\log _{\_}$priv $h c_{\_} y r_{-} s c h$ (logarithm of priv_hc_yr_sch), log_pub_hc_reg and $\log \_p u b \__{-} c_{-} s m$, i.e., predominantly proxies of $p u b H C_{i, j t}$ (in theory, even the average level of schooling could be interpreted as an institution-based variable). This is not valid at the level of marginal effects (values of coefficients), thus not allowing us to confirm $\mathrm{H} 3\left(\beta_{\text {institutions }}>\beta_{\text {culture }}\right)$, at least not according to how privHC $C_{i, j t}$ is defined. However, the regression coefficients of most proxies of $p r i v H C_{i, j t}$, as it was indicated in the data section, fell "victim"” to panel effects $u$; consult Table 5: the invariability in time of the Hofstede data made them perfectly collinear and automatically omitted.

Table 5: Summary statistics for panel effects in pure Olson model

\begin{tabular}{l|c|c|c|c|c}
\hline \multicolumn{7}{c}{ Pure Olson, USD, current prices } \\
\hline Variable & Obs. & Mean & Std. dev. & Min. & Max. \\
\hline$u$ & 314 & $1.49 \mathrm{e}-09$ & 0.3210443 & -0.7070257 & 1.078343 \\
\hline \multicolumn{7}{c}{ Pure Olson, LCU, current prices } \\
\hline Variable & Obs. & Mean & Std. dev. & Min. & Max. \\
\hline$u$ & 344 & $3.16 \mathrm{e}-09$ & 2.699826 & -3.736354 & 8.021041 \\
\hline
\end{tabular}

Source: authors, Stata

The regression coefficients in (2), (3) and (4) seem to be strongly influenced by the economic variables, $\log _{-} w l_{-} l c u \_m$ and $\log _{-} k_{-} l c u \_p e r \_l$, whilst the importance of Olson's factors varies and is mostly dissimilar to (1) with the exception of (3) in the US dollar terms. The biggest improvement in the adj. $\mathrm{R}^{2}$ seems to be caused by $\log _{-} k_{-} l c u \_p e r \_l$ 
(capital-to-labour ratio, $K / L$ ), characteristic of the VES production function. To test whether log_k_lcu_per_l, privHC$C_{i, j t}$ and $p u b H C_{i, j t}$ are not collinear in (3), we perform an additional estimation, the results of which are presented in Tables 6 and 7.

Table 6: K/L share vs. culture and institutions, USD, current prices, robust std. errors

\begin{tabular}{|c|c|c|c|}
\hline & (1) & (2) & (3) \\
\hline & Pooled & Fixed effects & Random effects \\
\hline log_priv_hc_yr_sch & $\begin{array}{l}0.8559^{* * * *} \\
(5.71)\end{array}$ & $\begin{array}{l}1.1472^{* * *} \\
(6.05)\end{array}$ & $\begin{array}{l}1.1493^{* * * *} \\
(7.32)\end{array}$ \\
\hline log_priv_hc_ind & $\begin{array}{l}0.1135 \\
(1.45)\end{array}$ & $\begin{array}{c}0.0000 \\
(.)\end{array}$ & $\begin{array}{l}0.4793^{* *} \\
(3.21)\end{array}$ \\
\hline log_priv_hc_uai & $\begin{array}{c}0.0245 \\
(0.26)\end{array}$ & $\begin{array}{c}0.0000 \\
(.)\end{array}$ & $\begin{array}{c}0.0894 \\
(0.32)\end{array}$ \\
\hline log_priv_hc_ltowvs & $\begin{array}{c}0.0514 \\
(0.63)\end{array}$ & $\begin{array}{c}0.0000 \\
(.)\end{array}$ & $\begin{array}{c}0.0403 \\
(0.32)\end{array}$ \\
\hline log_pub_hc_cpi & $\begin{array}{l}0.8668^{* * * *} \\
(4.80)\end{array}$ & $\begin{array}{c}0.1633 \\
(1.40)\end{array}$ & $\begin{array}{l}0.2790^{* *} \\
(2.64)\end{array}$ \\
\hline log_pub_hc_lspr & $\begin{array}{c}0.4379 \\
(1.22)\end{array}$ & $\begin{array}{c}-0.3297^{*} \\
(-2.27)\end{array}$ & $\begin{array}{c}-0.2127 \\
(-1.49)\end{array}$ \\
\hline log_pub_hc_sm & $\begin{array}{c}0.1260 \\
(1.01)\end{array}$ & $\begin{array}{c}0.0016 \\
(0.03)\end{array}$ & $\begin{array}{c}-0.0020 \\
(-0.04)\end{array}$ \\
\hline $\log _{-} p u b \_h c_{-} f t i$ & $\begin{array}{c}0.8109^{*} \\
(2.05)\end{array}$ & $\begin{array}{c}0.2454 \\
(1.75)\end{array}$ & $\begin{array}{c}0.2902^{*} \\
(2.00)\end{array}$ \\
\hline log_pub_hc_reg & $\begin{array}{c}-0.6632 \\
(-1.78)\end{array}$ & $\begin{array}{c}0.3879 * * \\
(3.14)\end{array}$ & $\begin{array}{l}0.3449 * * \\
(2.70)\end{array}$ \\
\hline _cons & $\begin{array}{l}4.4218^{* * *} \\
(4.10)\end{array}$ & $\begin{array}{l}7.9126^{* * *} \\
(12.60)\end{array}$ & $\begin{array}{l}4.9280^{* * *} \\
(3.42)\end{array}$ \\
\hline$N$ & 344 & 344 & 344 \\
\hline Adj. $R^{2}$ & 0.6630 & 0.4930 & - \\
\hline RMSE & 0.6390 & 0.1218 & 0.1564 \\
\hline AIC & 677.9087 & $-4.7 \mathrm{E}+02$ & - \\
\hline $\mathrm{BIC}$ & 716.3151 & $-4.4 \mathrm{E}+02$ & - \\
\hline
\end{tabular}

Note: $t$ statistics in parentheses; ${ }^{*} p<0.05,{ }^{* *} p<0.01,{ }^{* * *} p<0.001$

Source: authors, Stata 
Table 7: K/L share vs. culture and institutions, LCU, current prices, robust std. errors

\begin{tabular}{|c|c|c|c|}
\hline & (1) & (2) & (3) \\
\hline & Pooled & Fixed effects & Random effects \\
\hline log_priv_hc_yr_sch & $\begin{array}{l}0.1091 \\
(0.31)\end{array}$ & $\begin{array}{l}3.2324^{* * *} \\
(7.44)\end{array}$ & $\begin{array}{l}2.2487^{* * *} \\
(6.26)\end{array}$ \\
\hline log_priv_hc_ind & $\begin{array}{c}-0.5382 \\
(-1.62)\end{array}$ & $\begin{array}{c}0.0000 \\
(.)\end{array}$ & $\begin{array}{c}-1.5766^{* *} \\
(-2.62)\end{array}$ \\
\hline log_priv_hc_uai & $\begin{array}{c}-0.4276 \\
(-1.40)\end{array}$ & $\begin{array}{c}0.0000 \\
(.)\end{array}$ & $\begin{array}{c}-0.9083 \\
(-1.18)\end{array}$ \\
\hline log_priv_hc_ltowvs & $\begin{array}{c}0.6384^{*} \\
(2.32)\end{array}$ & $\begin{array}{c}0.0000 \\
(.)\end{array}$ & $\begin{array}{c}-0.1070 \\
(-0.21)\end{array}$ \\
\hline log_pub_hc_cpi & $\begin{array}{c}-0.0898 \\
(-0.21)\end{array}$ & $\begin{array}{c}0.6077 \\
(1.86)\end{array}$ & $\begin{array}{c}0.4748 \\
(1.39)\end{array}$ \\
\hline log_pub_hc_lspr & $\begin{array}{c}-0.9527 \\
(-0.90)\end{array}$ & $\begin{array}{c}-0.6731 \\
(-1.45)\end{array}$ & $\begin{array}{c}-0.6356 \\
(-1.46)\end{array}$ \\
\hline log_pub_hc_sm & $\begin{array}{l}1.8419^{* * *} \\
(4.66)\end{array}$ & $\begin{array}{c}0.3761 \\
(1.90)\end{array}$ & $\begin{array}{l}0.4041^{*} \\
(2.21)\end{array}$ \\
\hline $\log \_p u b \_h c \_f t i$ & $\begin{array}{c}-0.5870 \\
(-0.37)\end{array}$ & $\begin{array}{l}1.1527 \\
(1.44)\end{array}$ & $\begin{array}{l}1.1129 \\
(1.41)\end{array}$ \\
\hline log_pub_hc_reg & $\begin{array}{c}0.3726 \\
(0.42)\end{array}$ & $\begin{array}{c}0.9637^{*} \\
(2.10)\end{array}$ & $\begin{array}{c}1.2614^{* *} \\
(2.73)\end{array}$ \\
\hline _cons & $\begin{array}{l}12.8245^{* * *} \\
(4.02)\end{array}$ & $\begin{array}{c}0.0888 \\
(0.04)\end{array}$ & $\begin{array}{l}12.1016^{* *} \\
(2.90)\end{array}$ \\
\hline$N$ & 342 & 342 & 342 \\
\hline $\operatorname{Adj} . R^{2}$ & 0.0660 & 0.6720 & - \\
\hline RMSE & 2.0993 & 0.2859 & 0.3815 \\
\hline AIC & $1.5 \mathrm{E}+03$ & 118.9804 & - \\
\hline $\mathrm{BIC}$ & $1.5 \mathrm{E}+03$ & 141.9893 & - \\
\hline
\end{tabular}

Note: $t$ statistics in parentheses; ${ }^{*} p<0.05,{ }^{* *} p<0.01,{ }^{* * *} p<0.001$

Source: authors, Stata

The adj. $R^{2}$ of the pooled (1) and fixed-effects (2) models, with the exception of (1) in LCU terms, lie in the interval of $49.3 \%-67.2 \%$, which is strong enough to confirm our suspicion. At the least, Olson's factors and economic variables in the examined models seem to be mutually dependent, i.e., interchangeable to a certain degree $(50 \%-60 \%$ in the case of the $K / L$ share, although not $100 \%$ ), which can be interpreted as a partial confirmation of Olson's theory (see the discussion section). 
To conclude, in order to account for a potential bias arising from the strict assumptions of the SMAC framework (which allow us to consider indirect and direct notations of production functions to be equivalent), we perform an additional estimation of (1) - (4) with the help of bootstrap resampling (i.e., disregarding the theory and inferring directly from the data). The results presented in Tables 8 and 9 provide us with bigger standard errors, more conservative adj. $R^{2}$, and therefore more confidence in the final result, whilst preserving all the regression coefficients intact (resampling techniques change standard errors and statistics affected by them but not the coefficient estimates).

Table 8: Estimations in SMAC notation, USD, current prices, FE with bootstrap std. errors

\begin{tabular}{|c|c|c|c|c|}
\hline & (1) & (2) & (3) & (4) \\
\hline & Pure Olson & Olson + CES & Olson + VES & General PF \\
\hline log_priv_hc_yr_sch & $\begin{array}{l}2.4859^{* * *} \\
(7.42)\end{array}$ & $\begin{array}{l}0.6932^{* *} \\
(2.59)\end{array}$ & $\begin{array}{c}0.2303 \\
(1.26)\end{array}$ & - \\
\hline log_priv_hc_ind & $\begin{array}{c}0.0000 \\
(.)\end{array}$ & $\begin{array}{c}0.0000 \\
(.)\end{array}$ & $\begin{array}{c}0.0000 \\
(.)\end{array}$ & - \\
\hline log_priv_hc_uai & $\begin{array}{c}0.0000 \\
(.)\end{array}$ & $\begin{array}{c}0.0000 \\
(.)\end{array}$ & $\begin{array}{c}0.0000 \\
(.)\end{array}$ & - \\
\hline log_priv_hc_ltowvs & $\begin{array}{c}0.0000 \\
(.)\end{array}$ & $\begin{array}{c}0.0000 \\
(.)\end{array}$ & $\begin{array}{c}0.0000 \\
(.)\end{array}$ & - \\
\hline $\log _{\text {ogp }}$ b_hc_cpi & $\begin{array}{l}0.3608^{*} \\
(2.08)\end{array}$ & $\begin{array}{c}0.0726 \\
(0.72)\end{array}$ & $\begin{array}{c}0.0198 \\
(0.36)\end{array}$ & - \\
\hline $\log _{-} p u b_{-} h c_{-} I s p r$ & $\begin{array}{c}-0.0538 \\
(-0.20)\end{array}$ & $\begin{array}{l}0.1197 \\
(0.68) \\
\end{array}$ & $\begin{array}{c}0.3138^{*} \\
(2.30)\end{array}$ & - \\
\hline $\log _{-} p u b \_h c_{-} s m$ & $\begin{array}{l}0.3400^{* * * *} \\
(5.78)\end{array}$ & $\begin{array}{c}0.0327 \\
(0.57)\end{array}$ & $\begin{array}{c}0.0903^{*} \\
(2.29)\end{array}$ & - \\
\hline log_pub_hc_fti & $\begin{array}{c}-0.4333 \\
(-1.76) \\
\end{array}$ & $\begin{array}{c}0.0091 \\
(0.06) \\
\end{array}$ & $\begin{array}{c}-0.2336^{*} \\
(-2.35)\end{array}$ & - \\
\hline $\log _{\text {p }} p u b_{-} h c_{-} r e g$ & $\begin{array}{c}0.8279 * * \\
(3.13)\end{array}$ & $\begin{array}{c}0.1699 \\
(1.54)\end{array}$ & $\begin{array}{c}0.0303 \\
(0.28)\end{array}$ & - \\
\hline $\log _{-} w \_m$ & - & $\begin{array}{l}0.8089^{* * *} \\
(11.11)\end{array}$ & $\begin{array}{l}0.6608^{* * *} \\
(13.85)\end{array}$ & $\begin{array}{l}0.7427^{* * * *} \\
(19.74)\end{array}$ \\
\hline $\log _{-} k_{-}$per_l & - & - & $\begin{array}{l}0.6725^{* * *} \\
(6.39)\end{array}$ & $\begin{array}{l}0.6802^{* * * *} \\
(8.25)\end{array}$ \\
\hline _cons & $\begin{array}{c}1.8047 \\
(1.93) \\
\end{array}$ & $\begin{array}{l}1.9934^{* * *} \\
(3.81)\end{array}$ & $\begin{array}{l}-3.4129^{* * * *} \\
(-4.06)\end{array}$ & $\begin{array}{c}-3.1386^{* * * *} \\
(-4.09)\end{array}$ \\
\hline$N$ & 344 & 314 & 314 & 345 \\
\hline Adj. $R^{2}$ & 0.4630 & 0.8510 & 0.9150 & 0.9080 \\
\hline RMSE & 0.2626 & 0.1422 & 0.1072 & 0.1162 \\
\hline
\end{tabular}

Note: $t$ statistics in parentheses; ${ }^{*} p<0.05,{ }^{* *} p<0.01,{ }^{* * *} p<0.001$

Source: authors, Stata 
Table 9: Estimations in SMAC notation, LCU, current prices, FE with bootstrap std. errors

\begin{tabular}{|c|c|c|c|c|}
\hline & (1) & (2) & (3) & (4) \\
\hline & Pure Olson & Olson + CES & Olson + VES & General PF \\
\hline log_priv_hc_yr_sch & $\begin{array}{l}3.0141^{* * *} \\
(7.31)\end{array}$ & $\begin{array}{l}2.6881^{* * * *} \\
(4.10)\end{array}$ & $\begin{array}{c}-0.0425 \\
(-0.18)\end{array}$ & - \\
\hline log_priv_hc_ind & $\begin{array}{c}0.0000 \\
(.)\end{array}$ & $\begin{array}{c}0.0000 \\
(.)\end{array}$ & $\begin{array}{c}0.0000 \\
(.)\end{array}$ & - \\
\hline log_priv_hc_uai & $\begin{array}{c}0.0000 \\
(.)\end{array}$ & $\begin{array}{c}0.0000 \\
(.)\end{array}$ & $\begin{array}{c}0.0000 \\
(.)\end{array}$ & - \\
\hline log_priv_hc_ltowvs & $\begin{array}{c}0.0000 \\
(.)\end{array}$ & $\begin{array}{c}0.0000 \\
(.)\end{array}$ & $\begin{array}{c}0.0000 \\
(.)\end{array}$ & - \\
\hline log_pub_hc_cpi & $\begin{array}{c}0.5308 \\
(1.80)\end{array}$ & $\begin{array}{c}0.3618 \\
(1.45)\end{array}$ & $\begin{array}{c}-0.0571 \\
(-0.93)\end{array}$ & - \\
\hline log_pub_hc_lspr & $\begin{array}{c}-0.4881 \\
(-0.99) \\
\end{array}$ & $\begin{array}{c}-0.6887 \\
(-1.41)\end{array}$ & $\begin{array}{l}0.1103 \\
(1.03) \\
\end{array}$ & - \\
\hline log_pub_hc_sm & $\begin{array}{c}0.4933 \\
(1.95)\end{array}$ & $\begin{array}{c}0.2816 \\
(1.16)\end{array}$ & $\begin{array}{c}0.1258 \\
(1.57)\end{array}$ & - \\
\hline log_pub_hc_fti & $\begin{array}{l}1.1009 \\
(1.27)\end{array}$ & $\begin{array}{c}0.9774 \\
(1.31)\end{array}$ & $\begin{array}{l}0.0136 \\
(0.08)\end{array}$ & - \\
\hline log_pub_hc_reg & $\begin{array}{c}0.9344 \\
(1.27)\end{array}$ & $\begin{array}{l}1.0799^{*} \\
(1.96)\end{array}$ & $\begin{array}{l}0.0176 \\
(0.20)\end{array}$ & - \\
\hline log_w_lcu_m & - & $\begin{array}{c}0.1979 \\
(1.06)\end{array}$ & $\begin{array}{c}0.0258 \\
(1.29)\end{array}$ & $\begin{array}{c}0.0405 \\
(1.39)\end{array}$ \\
\hline log_k_lcu_per_l & - & - & $\begin{array}{l}0.9363^{* * *} \\
(19.70)\end{array}$ & $\begin{array}{l}0.9702^{* * *} \\
(25.72)\end{array}$ \\
\hline _cons & $\begin{array}{c}-0.6878 \\
(-0.34)\end{array}$ & $\begin{array}{c}-0.5437 \\
(-0.29)\end{array}$ & $\begin{array}{c}-0.7450 \\
(-1.51)\end{array}$ & $\begin{array}{c}-1.1063^{* * *} \\
(-3.62)\end{array}$ \\
\hline$N$ & 344 & 314 & 312 & 343 \\
\hline $\operatorname{Adj} . R^{2}$ & 0.5070 & 0.5890 & 0.9660 & 0.9610 \\
\hline RMSE & 0.3508 & 0.3289 & 0.0941 & 0.1060 \\
\hline
\end{tabular}

Note: $t$ statistics in parentheses; ${ }^{*} p<0.05,{ }^{* *} p<0.01,{ }^{* * *} p<0.001$

Source: authors, Stata

The fixed-effects models (FE) with bootstrap resampling suggest adj. $R^{2}$ that is $15-20$ percentage point lower than FE with robust standard errors in the case (1), bigger RMSE and standard errors, which leads to re-evaluation of some $t$-tests for local currency terms into an unfavourable direction, rendering the latter almost invalid (with the exception

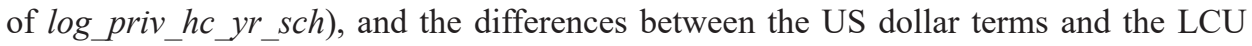


even more pronounced. This seems to highlight the significance of exchange rates (and prices) even in simple econometric models such as the SMAC.

\section{Discussion}

Olson ( 1996 ; 1998) was sceptical of the orthodox approach to explaining differences in wealth between countries, which includes the logic behind the production function model. Still, in econometric terms, the production or "pseudo-production" (Olson-based or any other) function predicting income on the left-hand side, being methodologically backed by a very loose theoretical concept such as the SMAC framework (Arrow et al., 1961; Lu and Fletcher, 1968), seems to be the only option to test a conjecture such as Olson's in a way which is compatible with mainstream economics. In this paper, we set three hypotheses for the "Olson function" we specified: H1 correct econometric specification, $\mathrm{H} 2$ high explanatory power, and $\mathrm{H} 3$ stronger marginal effects of institutions and policies. Both the fixed-effects model with robust (and subsequently bootstrapped) standard errors which we estimated on the available data supported only the first hypothesis (H1), which means that Olson's conjecture claiming culture and institutions being able to predict income seems to be econometrically sound. Still, the model was able to explain only $40-60 \%$ of the variability, which can of course be caused by the data sample (the quality of proxy variables, the existence of missing values, etc.), but it can also point to the fact that institutional factors (or at least the variables defined by Olson) cannot fully explain the variability of wealth in the world, which we believe should be the main conclusion. Nevertheless, we found strong evidence that Olson's factors are interdependent not only with income but also with the most significant economic terms in the production function, such as the $K / L$ share (50-60\% of its variability can be explained by culture and institutions), which makes the production function and Olson's "pseudo-production function" interchangeable by at least 50\% (and probably more). Finally, we were unable to estimate quantitative superiority of institutions over culture in terms of marginal effects (at least not in the definition adopted from Olson) but the proxy variables for them were statistically more significant. The results are robust and, although we could not prove the full validity of Olson's conjecture econometrically (that culture and institutions are the factors explaining differences in wealth across countries), we believe its philosophy and logic to be valid, which is in accord with several previous studies on the topic, such as Tabellini (2008; 2010), Williamson (2009), Law et al. (2013) or Kapas and Czegledi (2017). In the light of these findings future research should probably focus on the quality of proxies for non-economic factors and on (multi)collinearity in hybrid models such as (2) and (3) in this paper. 


\section{Conclusion}

The answer to the question "Why are some countries rich and some poor?" should be at the core of any macroeconomic research. Yet, disentangling the great variety of influences on economic development of a country is notoriously difficult to do by means of econometrics so that the result would provide a degree of confidence. We have attempted to follow in the footsteps of Mancur Olson in his claim that there is substantial influence of institutions and policies and, to a lesser extent, culture on economic development. We have found an econometric version of Olson's "model" to be correctly specified, and of explanatory power similar to a mainstream economic production function. 


\section{Appendix}

\section{Data summary}

\begin{tabular}{|c|c|c|c|c|c|}
\hline Variable & Obs. & Mean & Std. dev. & Min. & Max. \\
\hline \multicolumn{6}{|c|}{ VALUE ADDED / INCOME } \\
\hline ngdp_lcu & 1,031 & $4.53 \mathrm{E}+07$ & $4.25 \mathrm{E}+08$ & $1.32 \mathrm{E}-05$ & $8.68 \mathrm{E}+09$ \\
\hline$n g d p$ & 1,031 & $2.40 \mathrm{E}+05$ & $1.00 \mathrm{E}+06$ & $7.47 \mathrm{E}+01$ & $1.61 \mathrm{E}+07$ \\
\hline ngdp_lcu_per_l & 385 & $2,106,296.00$ & $7,358,622.00$ & 67.35 & $73,600,000.00$ \\
\hline ngdp_per_l & 385 & $33,605.36$ & $36,144.34$ & 409.79 & $238,590.40$ \\
\hline \multicolumn{6}{|c|}{ INPUTS - ORTHODOX (Z) } \\
\hline k_lcu & 1,023 & $1.47 \mathrm{E}+08$ & $1.50 \mathrm{E}+09$ & $3.00 \mathrm{E}-05$ & $3.23 E+10$ \\
\hline$k$ & 1,031 & $1.35 \mathrm{E}+06$ & $4.24 \mathrm{E}+06$ & $8.03 E+02$ & $5.51 \mathrm{E}+07$ \\
\hline k_lcu_per_l & 383 & $6,290,866.00$ & $23,000,000.00$ & 160.61 & $274,000,000.00$ \\
\hline k_per_l & 385 & $176,169.50$ & $152,803.90$ & 3884.90 & $1,232,011.00$ \\
\hline I & 385 & 17.46 & 42.27 & 0.05 & 386.37 \\
\hline \multicolumn{6}{|c|}{ INPUTS - OLSON (Z) } \\
\hline priv_hc_yr_sch & 945 & 6.83 & 3.39 & 0.08 & 13.49 \\
\hline priv_hc_ind & 1,078 & 36.01 & 18.77 & 6.00 & 91.00 \\
\hline priv_hc_uai & 1,078 & 64.68 & 20.94 & 8.00 & 100.00 \\
\hline priv_hc_ltowvs & 1,078 & 38.88 & 23.00 & 4.00 & 100.00 \\
\hline$p u b \_h c_{-} c p i$ & 1,078 & 43.32 & 21.19 & 2.00 & 98.00 \\
\hline pub_hc_lspr & 777 & 5.12 & 1.80 & 1.17 & 8.97 \\
\hline pub_hc_sm & 817 & 7.18 & 2.19 & 0.00 & 9.83 \\
\hline$p u b \_h c \_f t i$ & 778 & 6.44 & 2.02 & 0.00 & 9.85 \\
\hline pub_hc_reg & 800 & 6.35 & 1.39 & 1.06 & 9.40 \\
\hline \multicolumn{6}{|c|}{ PRICES } \\
\hline e & 1,037 & 350.99 & 1610.79 & 0.00 & $20,406.42$ \\
\hline$w \_l c u \_m$ & 844 & $150,322.50$ & $1,314,384.00$ & $3.27 \mathrm{E}-08$ & $3.53 \mathrm{E}+07$ \\
\hline$w_{-} m$ & 844 & 958.84 & 1284.22 & 14.31 & 8074.22 \\
\hline \multicolumn{6}{|c|}{ NOTES_AND_REMARKS } \\
\hline note_l & - & - & - & - & - \\
\hline note_e & - & - & - & - & - \\
\hline note_w & - & - & - & - & - \\
\hline note_w_labsh & - & - & - & - & - \\
\hline
\end{tabular}

Note: Countries included in the analysis are Angola, Albania, United Arab Emirates, Argentina, Armenia, Australia, Austria, Azerbaijan, Burundi, Belgium, Benin, Burkina Faso, Bangladesh, Bulgaria, Bahrain, Bahamas, Bosnia and Herzegovina, Belarus, Belize, Bolivia, Brazil, Barbados, Brunei, Bhutan, Botswana, 
Canada, Switzerland, Chile, China, Côte d'Ivoire, Congo, Colombia, Costa Rica, Cyprus, Czech Republic, Germany, Djibouti, Dominica, Denmark, the Dominican Republic, Algeria, Ecuador, Egypt, Spain, Estonia, Ethiopia, Finland, Fiji, France, Gabon, the United Kingdom, Georgia, Ghana, Gambia, Greece, Guatemala, Hong Kong, Honduras, Croatia, Haiti, Hungary, Indonesia, India, Ireland, Iran, Iraq, Iceland, Israel, Italy, Jamaica, Jordan, Japan, Kazakhstan, Kenya, Kyrgyzstan, Cambodia, South Korea, Kuwait, Lebanon, Liberia, Saint Lucia, Sri Lanka, Lesotho, Lithuania, Luxembourg, Latvia, Macao, Morocco, Moldova, Madagascar, Mexico, North Macedonia, Mali, Malta, Montenegro, Mongolia, Mozambique, Mauritius, Malawi, Malaysia, Namibia, Niger, Nigeria, Nicaragua, the Netherlands, Norway, Nepal, New Zealand, Oman, Pakistan, Panama, Peru, the Philippines, Poland, Portugal, Paraguay, Qatar, Romania, Russia, Rwanda, Saudi Arabia, Sudan, Senegal, Singapore, Sierra Leone, El Salvador, Serbia, Sao Tome and Principe, Suriname, Slovakia, Slovenia, Sweden, Swaziland, Seychelles, Syria, Thailand, Tajikistan, Turkmenistan, Trinidad and Tobago, Tunisia, Turkey, Tanzania (Mainland), Uganda, Ukraine, Uruguay, the United States, Uzbekistan, St. Vincent and the Grenadines, Venezuela, Vietnam, Yemen, South Africa, Zambia and Zimbabwe.

Source: authors

\section{References}

Acemoglu, D. (2009). Introduction to Modern Economic Growth. Princeton: Princeton University Press. ISBN 9780691132921.

Acemoglu, D., Johnson, S., Robinson, J. (2005). The Rise of Europe: Atlantic Trade, Institutional Change, and Economic Growth. American Economic Review, 95(3), 546-579, https://doi.org/10.1257/0002828054201305

Aghion, P., Howitt, P., Bursztyn, L. (2009). The Economics of Growth. Cambridge, Mass: MIT Press. ISBN 9780262012638.

Arrow, K. J., Chenery, H. B., Minhas, B. S., et al. (1961). Capital-Labor Substitution and Economic Efficiency. The Review of Economics and Statistics, 43(3), 225-250, https://doi.org/10.2307/1927286

Beugelsdijk, S. (2006). A Note on the Theory and Measurement of Trust in Explaining Differences in Economic Growth. Cambridge Journal of Economics, 30(3), 371-387, https://doi.org/10.1093/cje/bei064

Boettke, P. J., Coyne, C. J., Leeson, P. T. (2008). Institutional Stickiness and the New

Development Economics. American Journal of Economics and Sociology, 67(2), 331-358, https://doi.org/10.1111/j.1536-7150.2008.00573.x

Borjas, G. J. (1985). Assimilation, Changes in Cohort Quality, and the Earnings of Immigrants. Journal of Labor Economics, 3(4), 463-489, http://doi.org/10.1086/29806585:i:4:p:463-89

Borjas, G. J. (1987). Self-Selection and the Earnings of Immigrants. The American Economic Review, 77(4), 531-553. Available at: http://www.jstor.org/stable/1814529

Clague, C. (1991). Relative Efficiency, Self-Containment, and Comparative Costs of Less Developed Countries. Economic Development and Cultural Change, 39(3), 507-530, https://doi.org/10.1086/451888

Coase, R. H. (1937). The Nature of the Firm. Economica, 4(16), 386-405, https://doi.org/10.1111/ j.1468-0335.1937.tb00002.x 
Coase, R. H. (1960). The Problem of Social Cost. The Journal of Law \& Economics, 3, 1-44.

Evan, T., Bolotov, I. (2014). The Weak Relation between Foreign Direct Investment and

Corruption: A Theoretical and Econometric Study. Prague Economic Papers, 23(4), 474-492, https://doi.org/10.18267/j.pep.494

Evan, T., Bolotov, I. (2017). Analysis of Dynamic Relationship Between Corruption and Foreign

Direct Investment. Proceedings from ANTIcorruption \& fraud: DETECTION \& MEASUREMENT.

Feenstra, R. C., Inklaar, R.,Timmer, M. P. (2016). Penn World Table 9.0.

Freeman, R. B., Oostendorp, R. H. (2001). The Occupational Wages around the World data file. International Labour Review, 140(4), 379-401, https://doi.org/10.1111/j.1564-913X.2001. tb00223.x

Freeman, R. B., Oostendorp, R. H. (2002). Wages Around the World: Pay across Occupations and Countries, in Freeman, R. B., ed., Inequality Around the World. London: Palgrave Macmillan UK, pp. 5-37, https://doi.org/10.1007/978-1-137-09971-6_2

Granato, J., Inglehart, R., Leblang, D. (1996). The Effect of Cultural Values on Economic Development:Theory, Hypotheses, and Some Empirical Tests. American Journal of Political Science, 40(3), 607-631, https://doi.org/10.2307/2111786

Guiso, L., Sapienza, P., Zingales, L. (2015). The Value of Corporate Culture. Journal of Financial Economics, 117(1), 60-76, https://doi.org/10.1016/j.jfineco.2014.05.010

Hayek, F. A. (1945). The Use of Knowledge in Society. The American Economic Review, 35(4), 519-530.

Hayek, F. A. (1955). Degrees of Explanation. The British Journal for the Philosophy of Science, 6(23), 209-225, https://doi.org/10.1093/bjps/vi.23.209

Hofstede, G. (2011). Dimensionalizing Cultures: The Hofstede Model in Context. Online Readings in Psychology and Culture, 2(1), https://doi.org/10.9707/2307-0919.1014

Jackson, W. A. (1993). Culture, Society and Economic Theory. Review of Political Economy, 5(4), 453-469, https://doi.org/10.1080/09538259300000031

Kahneman, D. (2011). Thinking, Fast and Slow. $7^{\text {th }}$ edition. New York: Farrar, Straus and Giroux.

Kapas, J., Czegledi, P. (2017). Institutions and Policies of Economic Freedom: Different Effects on Income and Growth. Economia Politica, 34(2), 259-282, https://doi.org/10.1007/ s40888-017-0063-5

Klump, R., Preissler, H. (2000). CES Production Functions and Economic Growth. The Scandinavian Journal of Economics, 102(1), 41-56, https://doi.org/10.1111/1467-9442.00183

Kurz, H. D. (1986). Classical and Early Neoclassical Economists on Joint Production. Metroeconomica, 38(1), 1-37, https://doi.org/10.1111/j.1467-999X.1986.tb00420.x

Lall, P., Featherstone, A. M., Norman, D. W. (2002). Productivity Growth in the Western Hemisphere (1978-94): The Caribbean in Perspective. Journal of Productivity Analysis, 17(3), 213-231, https://doi.org/10.1023/A:1015008020851

Law, S. H., Lim, T. C., Ismail, N. W. (2013). Institutions and Economic Development: A Granger Causality Analysis of Panel Data Evidence. Economic Systems, 37(4), 610-624, https://doi.org/10.1016/j.ecosys.2013.05.005 
Lu, Y.-c., Fletcher, L. B. (1968). A Generalization of the CES Production Function. The Review of Economics and Statistics, 50(4), 449-452, https://doi.org/10.2307/1926812

Lucas, R. E. (1990). Why Doesn't Capital Flow from Rich to Poor Countries. The American Economic Review, 80(2), 92-96. Available at: http://www.jstor.org/stable/2006549

Mankiw, N. G., Romer, D., Weil, D. N. (1992). A Contribution to the Empirics of Economic Growth. The Quarterly Journal of Economics, 107(2), 407-437, https://doi. org/10.2307/2118477

Mantzavinos, C., North, D. C., Shariq, S. (2004). Learning, Institutions, and Economic Performance. Perspectives on Politics, 2(1), 75-84, https://doi.org/10.1017/ s1537592704000635

Mathers, R. L., Williamson, C. R. (2011). Cultural Context: Explaining the Productivity of Capitalism. Kyklos, 64(2), 231-252, https://doi.org/10.1111/j.1467-6435.2011.00504

von Mises, L. (1951). Socialism: An Economic and Sociological Analysis. London: Yale University Press.

Mishra, S. K. (2007). A Brief History of Production Functions. SSRN, https://doi.org/10.2139/ ssrn. 1020577

North, D. C. (1958). Ocean Freigt Rates and Economic Development 1750-1913. The Journal of Economic History, 18(4), 537-555, https://doi.org/10.1017/s0022050700107739

North, D. C. (1963). Quantitative Research in American Economic History. The American Economic Review, 53(1), 128-130.

North, D. C. (1968). Sources of Productivity Change in Ocean Shipping. Journal of Political Economy, 76(5), 953-970, https://doi.org/10.1086/259462

North, D. C. (1989). Institutional Change and Economic History. Journal of Institutional and Theoretical Economics, 145(1), 238-245.

North, D. C. (1990). Institutions, Institutional Change, and Economic Performance. Cambridge; New York: Cambridge University Press.

North, D. C. (1992). Institutions, Ideology, and Economic Performance. Cato Journal, 11(3), 477-496.

North, D. C. (1994). Economic Performance Through Time. The American Economic Review, 84(3), 359-368.

North, D. C. (1995). Economic Theory in a Dynamic Economic World. Business Economics, 30(1), 7-12.

Olson, M. (1982). The Rise and Decline of Nations. New Haven: Yale University Press.

Olson, M. (1987). Economic Nationalism and Economic Progress. The World Economy, 10(3), 241-264, https://doi.org/10.1111/j.1467-9701.1987.tb00099.x

Olson, M. (1996). Distinguished Lecture on Economics in Government: Big Bills Left on the Sidewalk: Why Some Nations are Rich, and Others Poor. The Journal of Economic Perspectives, 10(2), 3-24, https://doi.org/10.1257/jep.10.2.3

Olson, M. (1998). Mancur Olson on the Key to Economic Development. Population and Development Review, 24(2), 369-379, https://doi.org/10.2307/2807980 
Pryor, F. L. (2008). Culture Rules: A Note on Economic Systems and Values. Journal of Comparative Economics, 36(3), 510-515, https://doi.org/10.1016/j.jce.2008.04.002

Revankar, N. S. (1971). A Class of Variable Elasticity of Substitution Production Functions. Econometrica, 39(1), 61-71, https://doi.org/10.2307/1909140

Robinson, J. (1953). The Production Function and the Theory of Capital. The Review of Economic Studies, 21(2), 81-106, https://doi.org/10.2307/2296002

Robinson, J. (1955). The Production Function. The Economic Journal, 65(257), 67-71, https://doi.org/10.2307/2227443

Rothbard, M. N. (2006). Making Economic Sense. Auburn: Ludwig von Mises Institute.

Schwartz, S. H. (1992). Universals in the Content and Structure of Values: Theoretical Advances and Empirical Tests in 20 Countries. In Advances in Experimental Social Psychology. Amsterdam: Elsevier, pp. 1-65, https://doi.org/10.1016/S0065-2601(08)60281-6

Shaikh, A. (2005). Nonlinear Dynamics and Pseudo-Production Functions. Eastern Economic Journal, 31(3), 447-466. Available at: http://www.jstor.org/stable/40326424

Shephard, R. W. (1970). Theory of Cost and Production Functions. Princeton: Princeton University Press.

Smith, A. (2007). Wealth of Nations. New York: Cosimo, Inc. ISBN 978-1602069404.

Smith, A. (2011). The Theory of Moral Sentiments. Kapaau (T.H.): Gutenberg Publishers. ISBN 978-1614279983.

Solow, R. M. (1957). Technical Change and the Aggregate Production Function. The Review of Economics and Statistics, 39(3), 312-320, https://doi.org/10.2307/1926047

Tabellini, G. (2008). Presidential Address: Institutions and Culture. Journal of the European Economic Association, 6(2-3), 255-294, https://doi.org/10.1162/JEEA.2008.6.2-3.255

Tabellini, G. (2010). Culture and Institutions: Economic Development in the Regions of Europe. Journal of the European Economic Association, 8(4), 677-716, https://doi.org/10.1111/j.1542-4774.2010.tb00537.x

Taleb, N. N. (2007). The Black Swan: The Impact of the Highly Improbable. New York: Random House Publishing Group.

Temple, J. (2006). Aggregate Production Functions and Growth Economics. International Review of Applied Economics, 20(3), 301-317, https://doi.org/10.1080/ 02692170600736052

Thaler, R. (1980). Toward a Positive Theory of Consumer Choice. Journal of Economic Behavior \& Organization, 1(1), 39-60, https://doi.org/10.1016/0167-2681(80)90051-7

Weber, M. (2011). Die protestantische Ethik und der Geist des Kapitalismus: Vollständige Ausgabe. C.H. Beck. ISBN 978-3406602009.

Williamson, C. R. (2009). Informal Institutions Rule: Institutional Arrangements and Economic Performance. Public Choice, 139(3-4), 371-387, https://doi.org/10.1007/ s11127-009-9399-x

Williamson, C. R., Mathers, R. L. (2011). Economic Freedom, Culture, and Growth. Public Choice, 148(3-4), 313-335, https://doi.org/10.1007/s11127-010-9656-z 